\title{
A Decision Support System for Land Allocation under Multiple Objectives in Public Production Forests in the Brazilian Amazon
}

\author{
Marco W. Lentini, ${ }^{1,2}$ Douglas R. Carter, ${ }^{3}$ and Alexander J. Macpherson ${ }^{3}$ \\ ${ }^{1}$ Institute for the People and Environment (IMAZON), Rua Domingos Marreiros 2020, 66060-160 Belém, PA, Brazil \\ ${ }^{2}$ Instituto Floresta Tropical (IFT), Rua dos Mundurucus 1613, 66025-660 Belém, PA, Brazil \\ ${ }^{3}$ School of Forest Resources and Conservation, University of Florida, P.O. Box 110410, Gainesville, FL 32611-0410, USA
}

Correspondence should be addressed to Marco W. Lentini, lentini@ift.org.br

Received 12 July 2010; Revised 20 September 2010; Accepted 5 October 2010

Academic Editor: John Sessions

Copyright (C) 2010 Marco W. Lentini et al. This is an open access article distributed under the Creative Commons Attribution License, which permits unrestricted use, distribution, and reproduction in any medium, provided the original work is properly cited.

Logging in natural forests is a vital economic activity in the Brazilian Amazon. However, illegal and unplanned logging is exhausting forests rapidly. In 2006, a new forestry law in Brazil (Lei 11,284/2006) established the legal framework to develop state and national public forests for multiple uses. To support public forest planning efforts, we combine spatially explicit data on logging profits, biodiversity, and potential for community use for use within a forest planning optimization model. While generating optimal land use configurations, the model enables an assessment of the market and nonmarket tradeoffs associated with different land use priorities. We demonstrate the model's use for Faro State Forest, a 636,000 ha forest embedded within a large mosaic of conservation units recently established in the state of Pará. The datasets used span the entire Brazilian Amazon, implying that the analysis can be repeated for any public forest planning effort within the region.

\section{Introduction}

Selective logging in natural forests, largely performed illegally on public lands, is a vital economic activity in the Brazilian Amazon (henceforth Amazônia). Forests are being depleted rapidly as adoption of sound forest management practices is still in the incipient stage $[1,2]$. In 2006, Brazil enacted the Public Forest Management Law (Lei 11284/2006), which focuses on the expansion and improved management of public forests, including the establishment of large areas of forest concessions. The Brazilian government seeks to manage public forests as a critical component of forest-based sustainable development through implementing a complex balance of multiple and often competing uses [3].

The Brazilian government estimates that up to 13 million ha of forest concessions could be established within the first 10 years of implementation of the Public Forest Management
Law (PMFL). In 2007, the Brazilian Forest Service (SFB) concluded the first inventory of public lands, a starting point for detailed land use planning within public forests. In June 2010, approximately 150,000 hectares of natural forests in Amazônia were already being harvested by private concessionaires. The major challenge facing public planners now lies in allocating land across multiple uses to meet multiple objectives, often with little information about socioeconomic and biological conditions.

The objective of this paper is to develop an analytical tool to support this decisionmaking. To meet this end, we combine the best available spatially explicit data on expected logging profits, biodiversity, and potential for community use for use within a land use optimization model. While generating optimal land use configurations conditioned upon policy objectives, the model enables an assessment of the market and nonmarket tradeoffs associated with different land use priorities. After developing the model 
conceptually and discussing the data used within the model, we demonstrate the model on a 636,000 ha public forest.

The importance of this study is demonstrated in two ways. First, our model is the first in Amazônia to our knowledge that solves a timber supply problem within a framework that allocates land across multiple uses. Second, while we demonstrate the model on a specific public forest area, the datasets we draw upon span the entire Amazônia, implying that the analysis can be repeated for any public forest planning effort within the region.

\section{Conceptual Background}

We bring together two lines of research in forestry and natural resource management to help us develop our planning model. First, we draw upon the mathematical programming literature on the conservation reserve site selection problem, which generally aims to conserve the maximum number of species at a minimum cost or using a minimum number of reserves [4-9]. Second, we draw upon harvest scheduling and tactical planning problems, such as the optimization of infrastructure (e.g., roads), minimization of logging costs, imposition of ecological constraints (e.g., adjacency constraints), and optimization of forest operations [10-12].

\section{The Forest Planning Optimization Model}

We begin by establishing the basic selective logging timber supply problem, where the decision variables determine the amount of volume per ha to harvest. In a given public forest, government seeks to maximize profits from logging. The volume harvested is constrained by the available merchantable timber volume in the forest and the milling capacity of the logging centers surrounding the public forest. In mathematical terms,

$$
\begin{gathered}
\pi=\sum_{i=1}^{n} \sum_{j=1}^{m} \sum_{k=1}^{z}\left(X_{i j k} P_{i j k} A_{i}\right), \\
\sum_{j=1}^{m} X_{i j k} \leq S_{i k} \quad \forall i, k, \\
\sum_{i=1}^{n} \sum_{k=1}^{z}\left(X_{i j k} A_{i}\right) \leq D_{j} \quad \forall j .
\end{gathered}
$$

The subscript $i=(1, \ldots, n)$ represents individual forest stands within a given public forest. Each stand $i$ has an annual harvestable area $A_{i}$ denominated in hectares. If the stand is harvested, the timber will travel to at least one of $m$ mills located in logging centers denoted by $j=(1, \ldots, m)$. There are $z$ commercial species which, for simplification, we categorize into timber value classes, denoted by $k=$ $(1, \ldots, z)$. The profitability of logging, represented by $P_{i j k}$ (in US $\$ \mathrm{~m}^{-3}$ ), varies across stands $i$, logging centers $j$, and timber value classes $k$. Timber volume $\left(\mathrm{m}^{3} \mathrm{ha}^{-1}\right)$ logged from stand $i$ and value class $k$ and transported to each center $j$ is represented by $X_{i j k}$.

Equation (1) maximizes total returns from logging, denoted by $\pi$ (in US\$), which is equal to the product of harvested volume per hectare, the profit per cubic meter harvested, and the area of the annually harvested stands summed across all stands $i$, logging centers $j$, and timber classes $k$. According to (2), timber harvests within each stand at a given value class are constrained to be equal to or less than $S_{i k}$, which is the available volume $\left(\mathrm{m}^{3} \mathrm{ha}^{-1}\right)$ of timber in each stand $i$ and value class $k$. Represented by (3), the total volume annually harvested and directed toward a given center cannot exceed the milling capacity for each logging center $j\left(D_{j}\right.$, in $\left.\mathrm{m}^{3}\right)$.

Next, we need to incorporate land uses other than timber concessions into the model. Each stand within a public forest is assumed to have an exclusive land use-a strong assumption given that many areas might have overlapping uses. However, as a result of diminishing returns from management effort for multiple activities within the same stand, landscape-scale multiple use planning is perhaps most efficient when each stand has a unique use [13]. Equation (1) is then modified and the objective of the program becomes maximizing profits from concessions constrained by a minimum number of stands - or a minimum score-assigned to alternative land uses. In our study, we consider community use and biodiversity conservation as possible alternative uses. Each stand is also assumed to have a potential coefficient for each land use alternative. In generalized mathematical terms,

$$
\begin{gathered}
\max _{X_{i j k}, Y_{i u}} \pi=\sum_{i=1}^{n} \sum_{j=1}^{m} \sum_{k=1}^{z} X_{i j k} P_{i j k} A_{i} \delta_{i u} Y_{i u}, \\
Y_{i u} \in\{0,1\}, \quad u=\text { LOGGING; } \\
\sum_{u=1}^{r} Y_{i u} \leq 1, \quad Y_{i u} \in\{0,1\} \forall i ; \\
\sum_{i=1}^{n} Y_{i u} \delta_{i u} \geq L_{u}^{*}, \quad Y_{i u} \in\{0,1\} \forall u \neq \text { LOGGING. }
\end{gathered}
$$

In this formulation, $u=(1, \ldots, r)$ represents mutually exclusive land use alternatives for each stand $i$. The land use choice for each stand $i$ is represented by a series of binary variables $Y_{i u}$, which take on a value of one if a particular land use is chosen, zero otherwise. The potential of each stand $i$ for each land use $u$ is assumed to be known and is denoted by $\delta_{i u}$. The parameter $\delta_{i u}$ is assigned a priori to be either binary $(0,1)$ or some other score assigned by the public planner, in the case the planner has information about the relative value of different stands $i$ for a given land use alternative. This is important for planners because it can accommodate values of noncommercial land uses in a more meaningful way.

Equation (4) maximizes profits from logging within a single year. Equation (5) imposes a constraint guaranteeing no more than a single land use choice per parcel. For simplicity, we assume that constant returns to scale across all land uses and no agglomeration effects between any stand and the spatial composition of the forest. However, we do permit the planner to specify the minimum number of stands allocated to each land use within the forest. Alternatively, the planner can impose a minimum score to be achieved for a given land use by assigning different weights 
for each land use. In either situation, expressed in (6), $L_{u}^{*}$ represents the policy-driven minimum number of stands or the minimum score across alternative nonlogging land uses.

\section{Data}

4.1. Study Site: The Calha Norte Region and the Faro State Forest. Calha Norte is a region north of the Amazon River, in the state of Pará (Figure 1). The region totals 132 million hectares (about one quarter of Amazônia) and is sparsely populated. Many logging centers are located along the southern and western edges of the region. As of 2007, Calha Norte contained 64 million hectares of protected areas. Embedded within Calha Norte, Faro State Forest (FSF) comprises 636,000 hectares (Figure 1). FSF is covered by dense forests and displays little evidence of use and human occupation in the extreme eastern and southern portions [14].

4.2. Timber Stock Estimates. Relatively little is known about timber species distribution in Amazônia. Because we want the model to be useful within any area of Amazonnia, we drew data from RadamBrasil, a 1970s-era project that still provides the most comprehensive survey of tree species in the region. Sales and Souza Jr. (unpublished) provided a coarse-scale map from RadamBrasil data of overall timber species volume above $35 \mathrm{~cm}$ of diameter at breast height (DBH). From this map, we estimated the harvestable volume of each timber value class (i.e., merchantable species with $\mathrm{DBH}>50 \mathrm{~cm}$ ) using inventory information from four forest sites in Pará (M. Schulze and L. Sobral, personal communication).

4.3. Milling Capacity at the Logging Centers. Lentini et al. [15] provided estimates of the timber-processing capacity in the logging centers of the Brazilian Amazon, including those in proximity to FSF (17 centers). Using unpublished data from IBAMA on the timber volume legally harvested in private lands in Calha Norte in 2004, we estimated the milling capacity from public lands as the difference between the timber consumption in the logging centers and the volume currently authorized for milling, which is equal to $900,000 \mathrm{~m}^{3}$ year $^{-1}$. As well-planned and executed harvesting on public lands is intended to replace illegal logging on these lands, this capacity estimate is a reasonable starting point for analysis until better data become available.

In the first set of model runs that follow, we first assume that the spatial distribution of mills remains static. In the second set of simulations, we assume that sawmills move into 14 urban centers close to the forest which currently have no sawmills, assuming new mills would be built to better take advantage of the legal timber supply from FSF.

4.4. Estimates of the Profitability of Logging. We drew upon previous efforts to estimate the spatially explicit profitability of logging [15-17]. These studies created maps identifying forests financially profitable for logging, based on wood prices and logging costs (i.e., harvesting, transportation, transaction, and processing costs). For this study, we adapted the previous models by estimating the net returns to logging (variable $P_{i j k}$, in $\mathrm{m}^{3} \mathrm{ha}^{-1}$ harvested), which we define here as the profit to the logger plus stumpage price paid for forest access. Prices and variable costs used in the analysis were collected in 2004 through field surveys executed by IMAZON in all 82 logging centers of Amazônia [15]. From this database, we used 519 interviews from the Calha Norte and surrounding centers. It is important to note that, because of data limitations, prices and costs are assumed to be constant throughout the analysis, even though regional and local timber markets will be affected if large quantities of legal timber become available. Three maps of profitability of logging were generated for the three timber value classes considered $(k)$ : high, medium, and low value. The transportation map used in the modeling incorporated information on formal and informal road transportation networks and navigable rivers using data from IBGE [18], Brandão Jr. and Souza Jr. [19], and IMAZON [14].

4.5. Potential Areas for Logging. We used an agricultural potential map IBGE [20] to identify areas within FSF with steep slopes. We assumed that net returns would decrease $30 \%$ in high-slope forests. Also, following the Brazilian law, logging in areas with slopes greater than $45^{\circ}$ is not permitted in the model. Areas forbidden for logging were assigned $\delta_{i u}=0$ for harvesting in the model.

4.6. Potential Areas for Biodiversity Conservation. A map from the Socio-Environmental Institute (ISA) [21], developed during an extensive consultation with specialists in 1999, identified land conservation priorities in Amazônia using a five-point system. This map was used to identify areas within the FSF with high potential $\left(\delta_{i u}=1\right.$ in the first scenario simulated and $\delta_{i u}=1$ to 5 in the second) for biodiversity conservation.

4.7. Potential Areas for Community Use. Barreto et al. [22] mapped forest areas with evidence of human occupation, including mining permits, deforested areas, urban zones, rural human settlements, and areas of forest fires identified between 1996 and 2006. The latter were assumed to be forests potentially being used by forest dwellers in their livelihood strategies $\left(\delta_{i u}=1\right.$ in the first scenario simulated and $\delta_{i u}=2$ or 3 in the second).

\section{Scenarios Simulated}

To perform the analysis, we first converted the FSF map $(636,000 \mathrm{ha})$ into raster format composed of 255 stands of uniform $25 \mathrm{~km}^{2}$ cell (2,500 ha) size. To give a better sense of the size of a cell in forest management terms, a cell of 2,500 hectares would represent a small-scale concession under the provisions of the PFML. This area would be sufficient to sustain a small mill that consumes about $2,100 \mathrm{~m}^{3}$ year $^{-1}$ or three logs per day. To reflect a typical 35-year cutting cycle requirement for forest management plans in natural forests in Brazil, each stand was divided into 35 annual harvesting units, thus the harvestable area $\left(A_{i}\right)$ for each 2,500 ha stand 


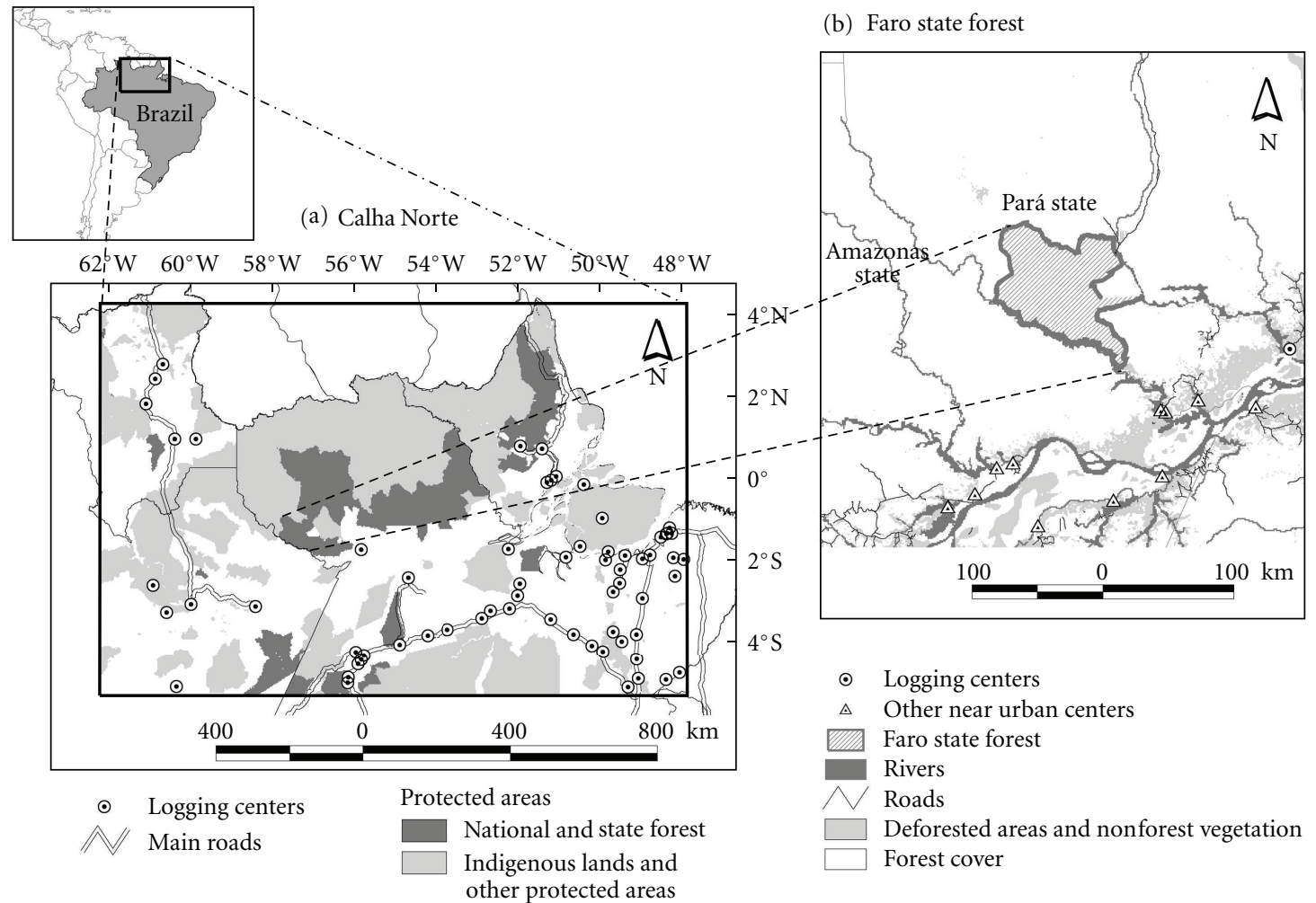

Figure 1: The Calha Norte region and Faro State Forest, Pará State, Brazil.

(i) is 71.4 ha. In other words, the economic model maximizes the annual profits originated from the annual allowable area for harvest of 71.4 ha. For simplicity, we assume that the growth and yield of the harvested forest would be sufficient to restore the same merchantable volume in each timber volume class $k$ within each stand at the beginning of the second cutting cycle.

Three competing land uses $(u)$ were considered: logging, biodiversity conservation, and community use. We simulated the production possibility frontier (PPF) and investigated the tradeoffs among different land uses for three scenarios using existing logging centers and also when the centers move to cities closer to FSF: an unconstrained logging (UL) scenario, in which logging is the unique land use and two multiple use scenarios imposing other alternative land uses within FSF. The first multiple use scenario uses a fixed weight ( 0 or 1 ) for the potential of the stands for alternative land uses $\left(\delta_{i u}\right)$, increasing the minimum number of stands assigned to community use and/or biodiversity conservation in order to analyze what would happen to logging profits, the number of stands, and the volume harvested within FSF and to trace out the PPF curves.

The second scenario investigates the impacts of varying the weights for stands potentially assigned to nonlogging land uses. In the case of community use, we assigned to stands in which older forest fires were identified (1996-2002) a weight equal to two-thirds the weight assigned to stands indicating more recent forest fire activity (2003-2006) (equal to 2 and 3, resp.). We also assigned an increasing gradient of weights (from 1 to 5 ) for biodiversity conservation as one moves from the western to eastern portions of FSF, since the eastern portion of the forest contains higher biodiversity, according to the ISA biodiversity priority map. It is not within the scope of this study to discuss whether these scores accurately capture the relative importance of stands for different uses, but rather to demonstrate the model's capability to use such information if and when it becomes available. In a full-blown application of the planning model within an actual forest planning context, it would be possible to use participatory techniques from multicriteria decision analysis to determine the relative weight of competing land uses.

In the two multiple use scenarios investigated, the potential $\left(\delta_{i u}\right)$ for logging was considered equal to 1 for any stand $i$ in which the estimate of logging profitability was greater than zero, and zero otherwise. All scenarios considered in this work assume a planning horizon equal to 40 years, which is the length of the contracts that have currently been established between the Brazilian Forest Services and concessionaires.

Currently, annual profits from logging represent one of the primary variables considered by the Brazilian Government in decisionmaking to grant concessions in public forests. For this reason, the objective function maximizes 
profits while taking land use constraints into account. However, to simulate the PPF curves and investigate the tradeoffs among competing land uses, we used annual profits (i.e., the profits generated by the optimization model) to calculate the NPV from logging concessions over the 40-year contract period, assuming that harvest behavior is the same in all periods. We then use the NPVs in the different scenarios simulated to determine the marginal opportunity arising from decreasing the area logged due to increasing requirements for alternative land uses. The calculation of the NPVs includes fixed establishment and audit costs that loggers incur to access concessions

$\mathrm{NPV}=\pi\left(\frac{1-(1+r)^{-n}}{r}\right)-C_{\text {aud }}\left(\frac{1-(1+r)^{-n}}{(1+r)^{t}-1}\right)-C_{\text {estab }}$,

where $\pi$ is the annual profits generated by the optimization model (in US\$); $n$ represents the length of the concessions contracts (40 years, according to the PFML). We assume a constant real discount rate, $r$, of $10 \%$. $C_{\text {aud }}$ represents the periodic audit costs. Every three years (the interval represented by $t$ ), Brazilian law requires independent audits of concessionaire performance within the concessions. Due to the lack of suitable data, audit costs were assumed to be equivalent to certification audit costs, which vary depending on the size of the management unit. We used US\$ $0.40 \mathrm{ha}^{-1}$ year $^{-1}$ (M. Voivodic, personal communication),

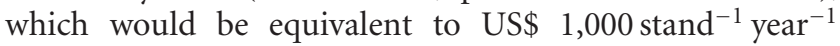
for logged stands. $C_{\text {estab }}$ represents the concession startup costs, which include forest inventories, preliminary studies, granting licenses, and auction processes. While in practice these costs will be specific to each concession, we assume that they are fixed and equal to US\$2 $\mathrm{ha}^{-1}$ (or US\$ 50,000 per stand assigned for logging by the model), based upon timber inventory survey costs born by private companies in Amazônia [23].

We also estimated the rent distribution between concessionaires and the government. We assumed that concessionaires would capture a profit level equal to $10 \%$ of wood prices, based upon the profit margins of timber firms operating on private lands [24]. The remaining profits are assumed to go to the government via a royalty mechanism that does not affect harvest decisionmaking.

The software used in the analyses was GAMS 22.4 (General Algebraic Modeling System). The unconstrained logging scenario discussed is a linear programming (LP) problem and was solved with CPLEX 10 solver. Nonlogging land uses introduce nonlinearities into the objective function, so the problem was solved using the DICOPT (Discrete and Continuous Optimizer), a solver for mixed integer nonlinear programming (MINLP) problems developed by Viswanathan and Grossmann [25]. DICOPT was chosen because it is robust and efficient compared to other MINLP solution methods [26]. For the largest problem that includes all land uses, the model solves for 13,005 continuous variables $\left(X_{i j k}\right)$ and 765 binary variables $\left(Y_{i u}\right)$, with 14,045 constraints. Execution times were about one-half second on a PC equipped with 3 GB RAM and a $1.6 \mathrm{GHz}$ Intel processor.

\section{Results}

In this section, we report a series of results from the model applied to FSF. While the results are useful for planning in FSF, our primary intention is to demonstrate the capability of the model to provide useful information to forest planners.

\subsection{The Timber Supply Problem}

6.1.1. The Unconstrained Logging (UL) Scenario. Considering timber harvests as the lone potential land use, 250 stands (98\% of FSF) would be harvested. The remaining stands cannot be harvested due to high slopes. About 17\% of FSF would have more than $70 \%$ of the volume harvested from both medium-value and high-value species (Figure 2(a)). In the remaining area, only high-value species would be logged. Total harvested volume would be equal to approximately $109,000 \mathrm{~m}^{3}$, which is equivalent to $12 \%$ of the milling capacity for timber from public forests in Calha Norte (Figure 3(a)). Logging companies would generate annual profits of about US\$ 3.2 million (Figure 4(a)). Processing would be performed by mills located in only three centers: Oriximiná, Santarém, and Uruará.

When mills relocate to cities closer to FSF, the same stands would be logged as before, but $25 \%$ of FSF would have all medium-value and high-value species logged, while $7 \%$ of FSF would have all available timber harvested (Figure 2(b)). Total volume harvested within FSF would rise to $168,519 \mathrm{~m}^{3}$, supplying $18 \%$ of the region's total milling capacity (the first bar of the Figure 3(b)). Annual profits from logging would increase to US\$ 4 million (Figure 4(b)). Harvesting would be performed mainly by Faro, Nhamundá, and Óbidos.

6.2. Interaction of Logging and Other Land Uses. Obviously, as the number of stands assigned to alternative land uses such as biodiversity conservation and use by communities is increased, the number of stands logged, timber volume harvested, and profits from logging decrease. Figures 2 and 3 show what happens to the number of stands assigned for logging and harvested volume when logging is performed by firms located in the current logging centers (Figures 2(a) and $3(\mathrm{a})$ ) and if mills move to closer cities (Figures 3(a) and $3(\mathrm{~b}))$.

6.3. Regional Milling Capacity. As discussed before, in the UL scenario with logging centers performing the harvests, only $12 \%$ of the regional milling capacity can be satisfied by FSF. When 122 stands, for example, are assigned to other uses, this proportion falls to $5 \%$. If the industry moves to closer cities, FSF could satisfy $18 \%$ of the regional milling capacity.

6.4. Annual Profits from Logging and Government Revenues. For decisionmaking purposes, it is important to be able to estimate the royalty rate that permits the logging firm to just satisfy participation constraints. Our assumption in the model is that the government is able to use an unspecified nondistortionary royalty instrument (that does not influence harvest behavior) to extract rents to the point 


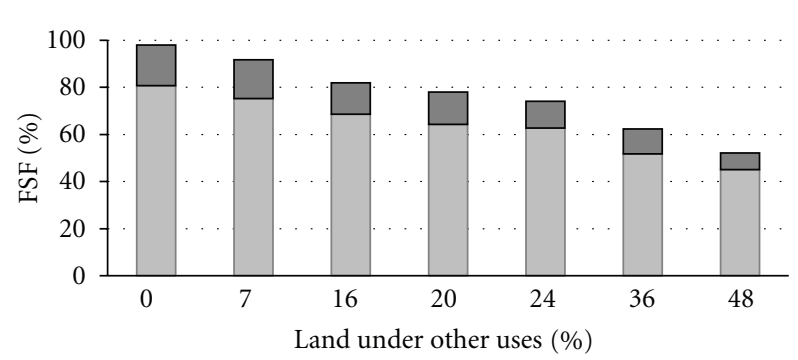

High + medium value spp.

Only high value spp.

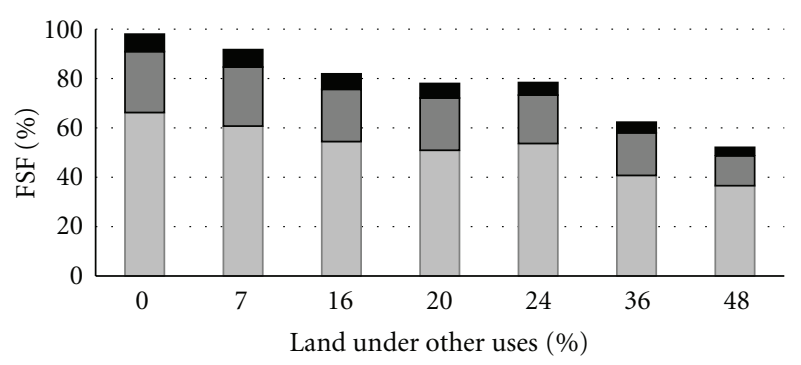

All spp. $\quad \square$ Only high value spp.

High + medium value spp.

(b)

FIgURE 2: Percentage of stands harvested within Faro State Forest with an increasing number of stands converted to other land uses from current logging centers (a) and from closer urban centers (b).

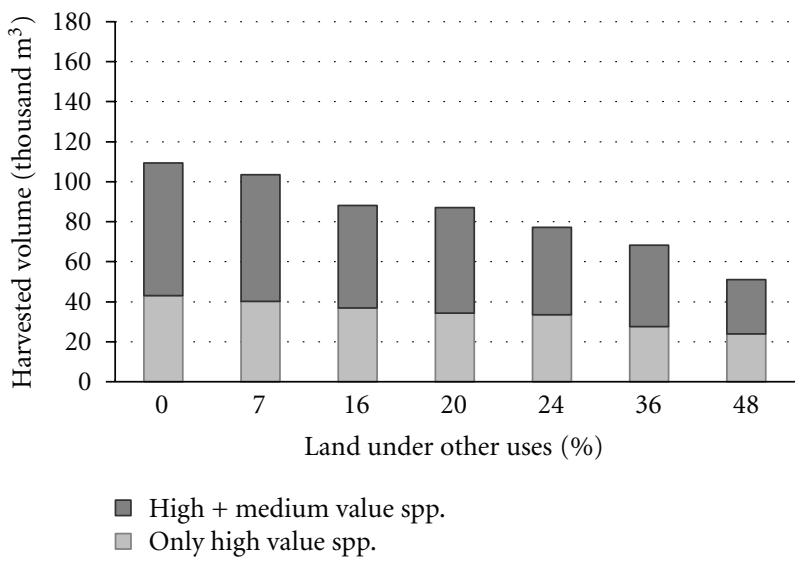

(a)

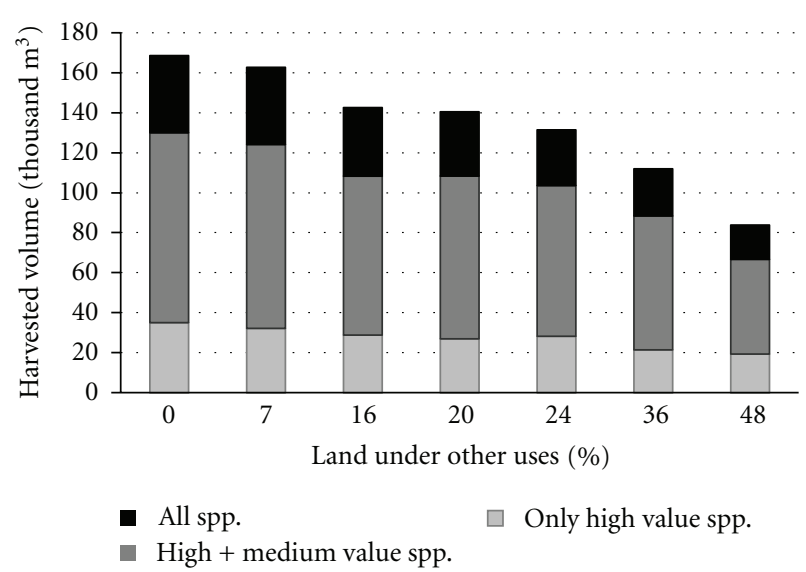

(b)

FIgURE 3: Volume harvested within Faro State Forest by timber value class with an increasing number of stands converted to other land uses from current logging centers (a) and from closer urban centers (b).

that concessionaires just earn profits equivalent to those of operating legally on private lands.

Figures 4(a) and 4(b) show the share of the profits for loggers and government under this assumption. Government would be able to extract around $28 \%-30 \%$ of the annual profits from logging if it is being performed by firms located within the surrounding logging centers (Figure 4(a)). Given total annual profits of US\$3.2 million in the UL scenario, US\$ 2.3 million would be considered normal profits to loggers, and US\$ 0.9 million would be paid to government. Figure 4(b) shows about the same distribution (in this case, $31 \%-33 \%$ ) if harvesting is performed by firms moving to cities closer to FSF.

Figures 4(c) and 4(d) show results when weights are differentiated across stands with noncommodity use potential. When imposing a minimum score to be achieved for biodiversity conservation varying from 100 to 500 (recall each stand can have a biodiversity value from 1 to 5 ), government would be able to extract a similar share of around 26\%-29\% of the profits (Figure 4(c)). Figure 4(d) shows the results of this scenario when a minimum total score for community use is imposed, in which government would be able to extract around $28 \%-29 \%$ of total profits.

6.5. The Production Possibility Frontier. PPFs examine tradeoffs between economic (NPV) and nonmarket objectives in FSF, assuming that harvests are performed from logging centers. In Figures 5(a) and 5(b), by applying equal weights for stands under these alternative uses, the maximum NPV reached is US\$ 16.8 million in the UL scenario. NPV decreased with an increase in the number of stands dedicated to communities. For example, when 30 stands (12\% of FSF) are allocated to community use, the NPV drops to US\$ 12.6 million (Figure 5(a)). Same effect is valid for biodiversity conservation. For example, when 110 stands are assigned to this land use, NPV decreased to US\$ 8.0 million (Figure 5(b)). Figures 5(c) and 5(d) show the frontier by applying differentiated weights for stands under these alternative uses, respectively, for community use and biodiversity conservation, using as a starting point the same NPV in the UL scenario. 


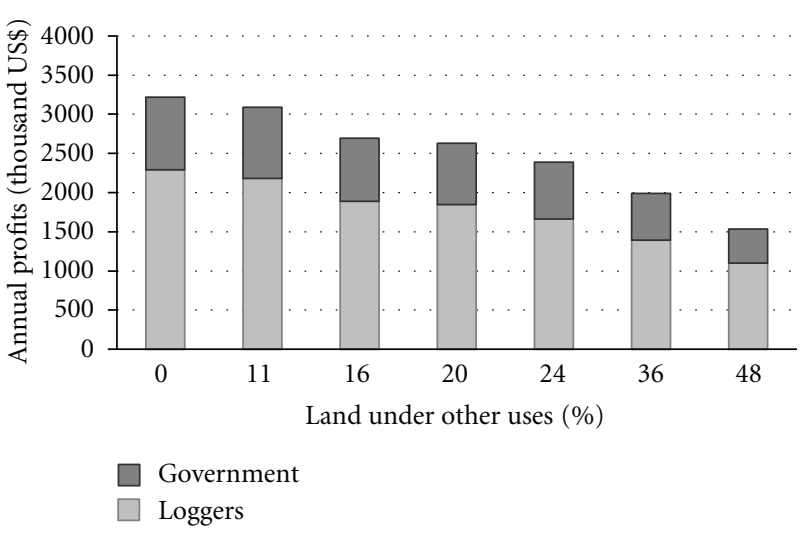

(a)

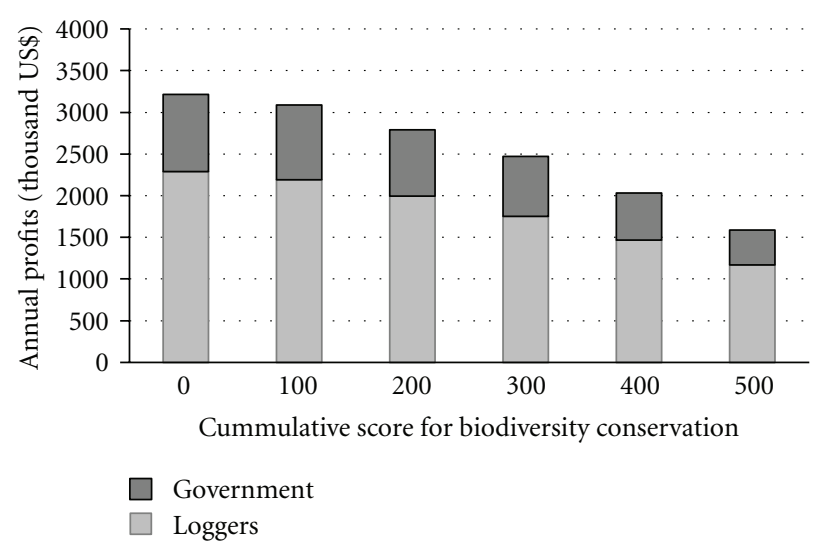

(c)

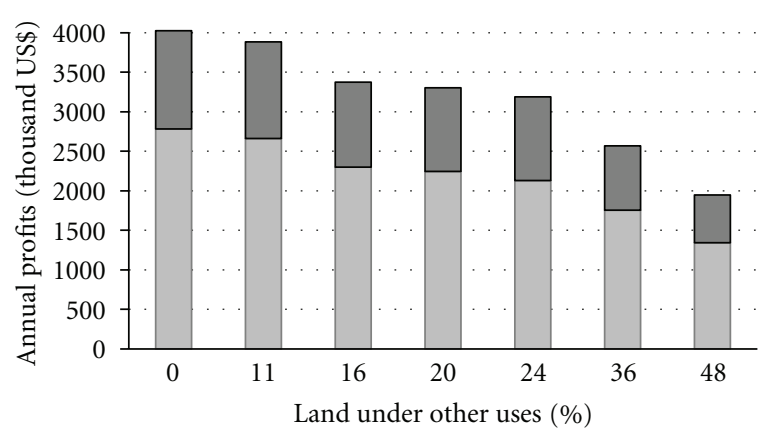

$\square$ Government $\square$ Loggers

(b)

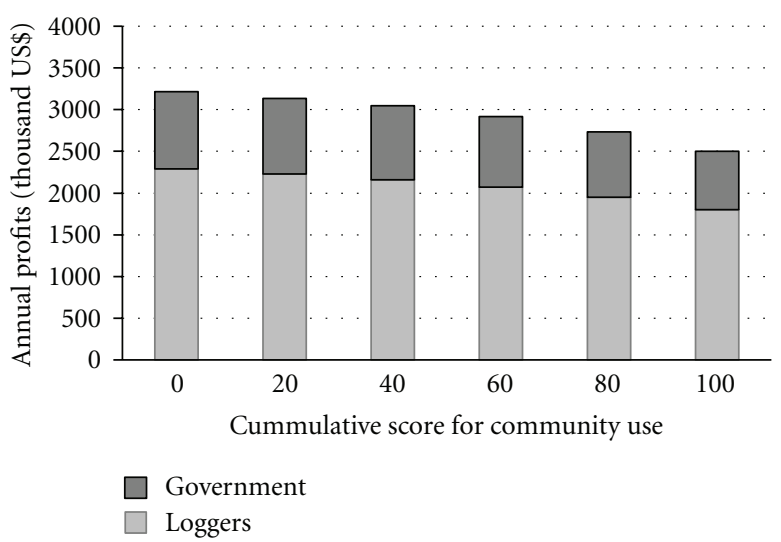

(d)

FIGURE 4: Annual profits from logging in Faro State Forest for government and loggers with an increasing number of stands in nonlogging land uses harvested by current logging centers (a) or from closer cities (b); annual profits from logging in Faro State Forest for government and loggers with an increasing cumulative score for biodiversity conservation (c) and for community use (d).

The curves traced out (mainly Figures 5(a) and 5(b) due to the similar comparative scale) are useful to assess the effects of nonlogging land use alternatives over the NPV generated by logging. In the case of FSF, the decrease in the NPV caused by an increase in the proportion of the State Forest dedicated to community use is larger than the decrease caused by biodiversity conservation, ceteris paribus. Note that, for example, when $12 \%$ of FSF is assigned to community use, the drop in the NPV from the UL scenario is equal to US\$ 4.1 million, while the same proportion assigned to biodiversity conservation would cause a decrease of only US\$ 0.6 million (Figures 5(a) and 5(b)). This is consistent with reality in the case of FSF since areas with higher potential for community use are located near roads and rivers that help access the forests (roads and rivers), which also creates higher profitability levels for logging.

6.6. Opportunity Costs for Alternative Land Uses. Zoning decisions in public forests, assuming that logging is the only revenue-generating activity, will create opportunity costs in terms of lost NPV. These opportunity costs are not uniform across every management decision. Figure 6 displays marginal opportunity cost (MOC) curves, which represent the cost of increasing one more percent of land use or one more point of cumulative score within FSF. Figure 6(a) depicts the MOC as more stands are assigned to communities. Figure 6(b) shows the same results for areas assigned to biodiversity conservation. Both curves assume equally weighted stands for both land uses. Figures 6(c) and $6(\mathrm{~d})$, otherwise, show the same curves considering the scenario with differentiated weights among stands with potential for community use and biodiversity conservation.

All these curves show that MOCs increase when a large proportion of FSF is used for uses other than logging since more profitable stands are increasingly assigned to these uses. For example, Figure 6(a) shows that MOCs are around US\$ 10,000 when few stands are assigned for community use and increase to US\$270,000 when 30 stands are assigned. The MOC for biodiversity conservation starts around US\$ 10,000 and increases to US\$ 170,000 when $43 \%$ of FSF ( 110 stands) is assigned for this land use (Figure 6(b)). In the same way, Figures 6(c) and 6(d) show increasing MOCs when more points are imposed for these alternative land 


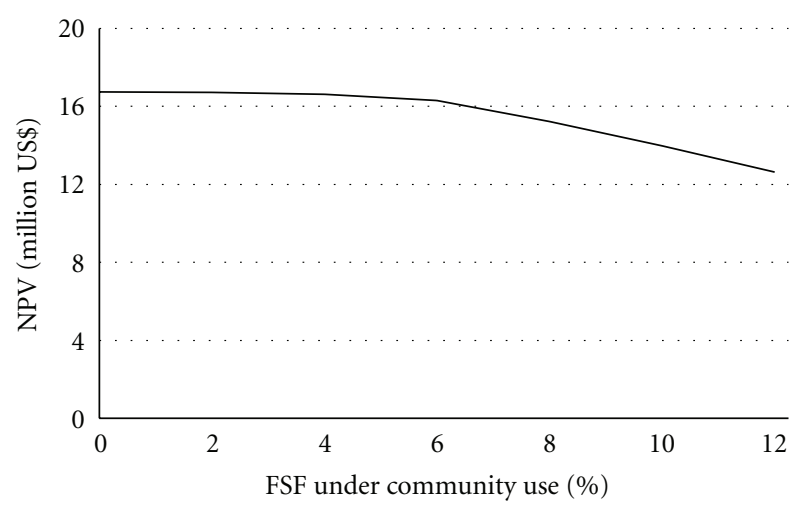

(a)

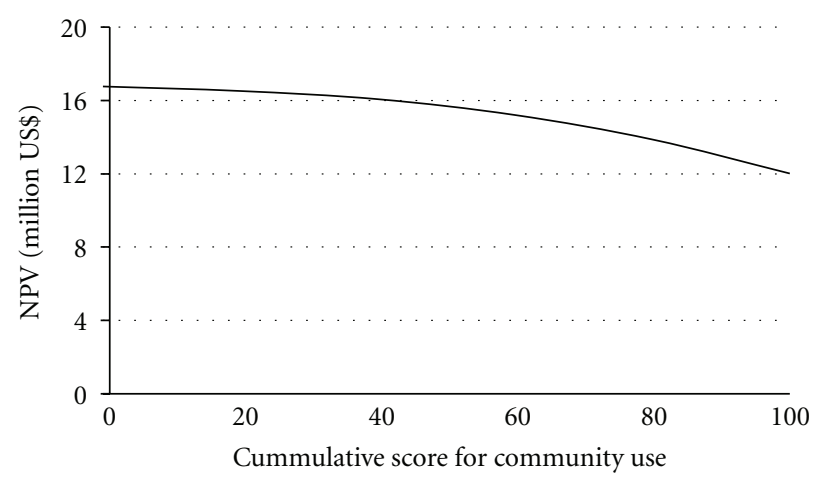

(c)

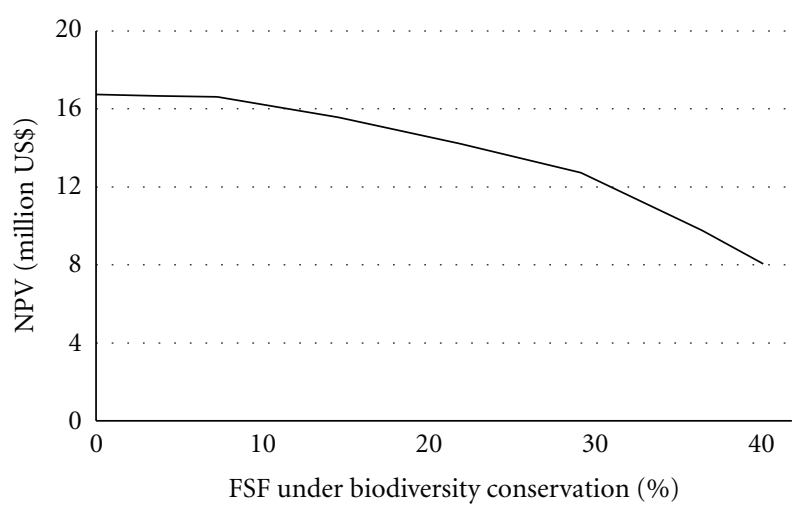

(b)

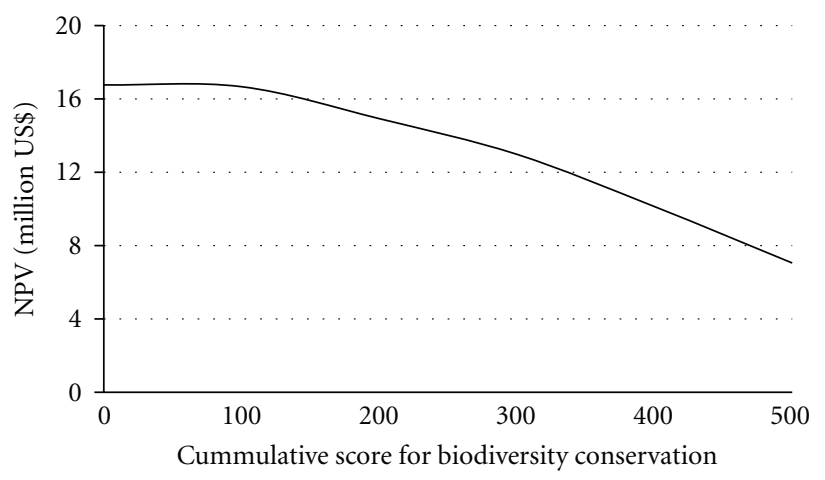

(d)

FIGURE 5: Production possibility frontiers for logging and livelihood systems (a) and logging and biodiversity conservation (b), assuming stands are weighted equally for nonlogging land uses within Faro State Forest; production possibility frontiers considering different weights among stands for nonlogging land uses, for logging and livelihood systems (c), and logging and biodiversity conservation (d). Harvests are assumed to be performed from current logging centers.

uses and, consistently, MOCs for each point imposed in this scenario are lower than MOCs for proportion of FSF. The same explanation given for the NPV curves in the last section is valid in explaining why MOCs for community use are larger than MOCs for biodiversity conservation since areas with potential for community use in the case of FSF are located near to roads and rivers and have higher profitability for logging.

\section{Discussion and Final Remarks}

The model has several potential uses. The model can be used to investigate the impacts of concessions from public forests on the local demand and supply for timber in a given region. Second, it can be used to estimate the revenues that can be generated from concessions and the taxes that can be collected by government through a nondistortionary royalty mechanism. Third, it can be used to investigate the tradeoffs among market and nonmarket uses in terms of reduced timber revenues. Fourth, at the landscape level, this model can help to determine the optimum level of timber production and spatial distribution of alternative land uses from public lands within a given region by taking into account future production trends of the logging industry.

Brazilian regulations establish that management decisions in each public forest will be guided by a management plan, which will be generated based on surveys in each public forest, including forest inventories, designated important sites for biological conservation and tourism, and the location and needs of traditional forest dwellers. The model developed in this study is not intended to replace these efforts but, rather, by incorporating data generated from these surveys, given planners a method to easily visualize alternative planning landscapes.

Our model is able to generate simple estimates of government rent capture, assuming concessionaires are only able to capture normal profits. The results show that concessions could represent an important source of funds for public agencies, relative to their current budgets. For example, in the unconstrained scenario, rents captured by government could be equivalent to US\$ 1.24 million year $^{-1}$ in FSF. If other public forests in Calha Norte were able to generate similar rents per unit of area, the Brazilian government could potentially generate US\$2 28 million year ${ }^{-1}$ from Calha Norte concessions. As a comparison, the 2007 budget for the Brazilian Forest Service is approximately US $\$ 13$ million [27].

These estimates assume that the government is able to fully capture rents. The experience across other countries shows that this assumption is extremely optimistic as governments have generally captured only a small proportion of the total rents $[28,29]$. Brazil is moving ahead with its plan to establish a forest concessions system while trying to take 


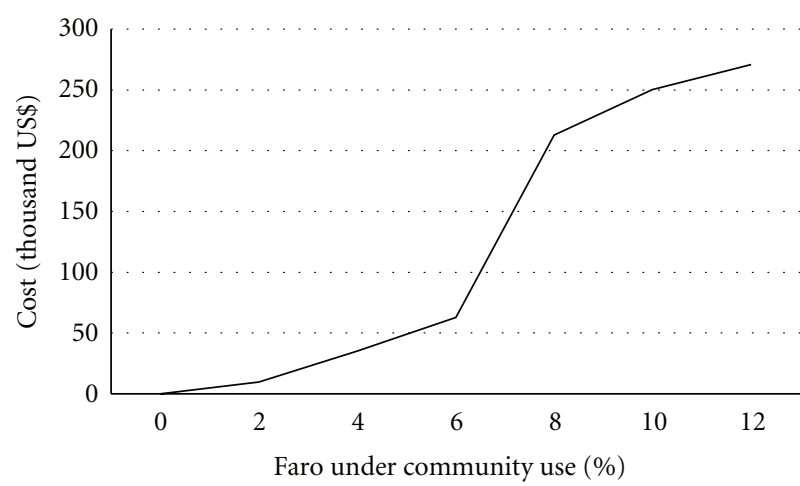

(a)

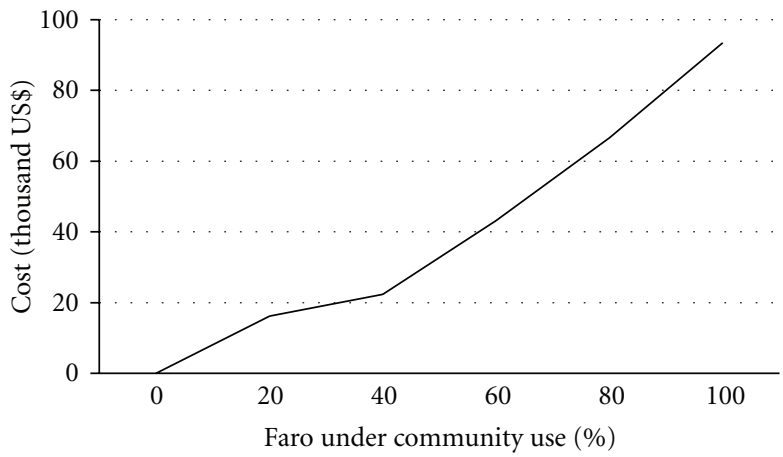

(c)

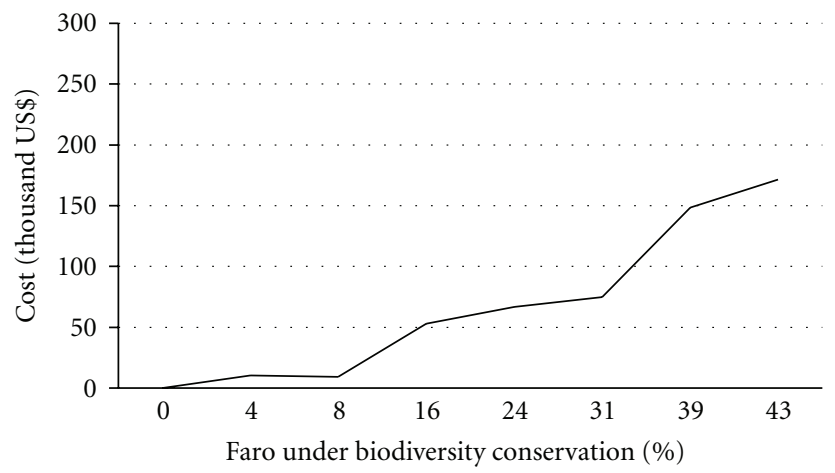

(b)

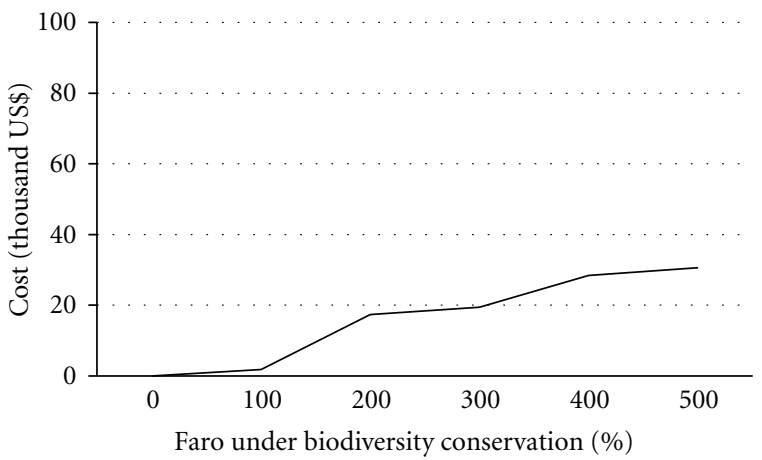

(d)

FIGURE 6: Marginal opportunity costs for community use (a) and biodiversity conservation (b), assuming stands are weighted equally for nonlogging land uses within Faro State Forest; marginal opportunity costs considering different weights among stands for nonlogging land uses for community use (c) and biodiversity conservation (d). Harvests are assumed to be performed from current logging centers.

full account of these experiences. Meanwhile, our estimates of government receipts should be viewed with caution.

\section{Further Research}

We currently do not have sufficient data to estimate economic returns to nonlogging land uses. Developing this information is an important priority for public forests planning. Further research should include forest dynamics to better incorporate the long-term growth and yield of the harvested forests. Further research could also incorporate different spatial configurations and sizes for stands destined for concessions to examine the costs and benefits of allocating concessions to firms of different sizes. Lastly, as the Brazilian concession experience expands, more accurate estimates of concession establishment costs, transaction costs generated by the licensing of forest management plans, and audit costs will be available for the better accuracy of the model. The usefulness for direct beneficiaries and for the society of stands set aside for land uses as community use and biodiversity conservation could be enhanced by assessing spatial zoning configurations which take into account the degree of connectivity among stands with the same land use alternative, which could be achieved by adding the appropriate constraints.

\section{Acknowledgments}

Datasets and technical assistance were provided by $\mathrm{R}$. Salomão, L. Sobral, M. Voivodic, and M. Schulze. Some data and suggestions were also provided by L. Sobral, M. Voivodic, and M. Schulze. M. Lentini would like to thank D. Zarin, J. Alavalapati, D. Lee, F. E. Putz, and C. Baraloto for comments and suggestions. The authors are also grateful to two anonymous reviewers for their valuable recommendations. The Amazon Conservation Leadership Initiative provided financial support for Lentini's graduate studies at University of Florida. A. J. Macpherson contributed to this work though he is a graduate student at the University of Florida, while receiving support from the Working Forests in the Tropics Program through a National Science Foundation Integrated Graduate Education and Research Traineeship Grant (no. DGE-0221599). Although this work was reviewed by the United States Environmental Protection Agency and approved for publication, it may not necessarily reflect official agency policy.

\section{References}

[1] G. P. Asner, D. E. Knapp, E. N. Broadbent, P. J. C. Oliveira, M. Keller, and J. N. Silva, "Ecology: selective logging in the 
Brazilian Amazon," Science, vol. 310, no. 5747, pp. 480-482, 2005.

[2] D. C. Nepstad, A. Veríssimo, A. Alencar et al., "Large-scale impoverishment of amazonian forests by logging and fire," Nature, vol. 398, no. 6727, pp. 505-508, 1999.

[3] A. Veríssimo, M. A. Cochrane, and C. Souza Jr., "Ecology: national forests in the Amazon," Science, vol. 297, no. 5586, p. 1478, 2002.

[4] R. L. Church, D. M. Stoms, and F. W. Davis, "Reserve selection as a maximal covering location problem," Biological Conservation, vol. 76, no. 2, pp. 105-112, 1996.

[5] A. Ando, J. Camm, S. Polasky, and A. Solow, "Species distributions, land values, and efficient conservation," Science, vol. 279, no. 5359, pp. 2126-2128, 1998.

[6] C. Costello and S. Polasky, "Dynamic reserve site selection," Resource and Energy Economics, vol. 26, no. 2, pp. 157-174, 2004.

[7] S. Polasky, J. D. Camm, and B. Garber-Yonts, "Selecting biological reserves cost-effectively: an application to terrestrial vertebrate conservation in Oregon," Land Economics, vol. 77, no. 1, pp. 68-78, 2001.

[8] S. Polasky, E. Nelson, E. Lonsdorf, P. Fackler, and A. Starfield, "Conserving species in a working landscape: land use with biological and economic objectives," Ecological Applications, vol. 15, no. 4, pp. 1387-1401, 2005.

[9] H. Önal and R. A. Briers, "Incorporating spatial criteria in optimum reserve network selection," Proceedings of the Royal Society B, vol. 269, no. 1508, pp. 2437-2441, 2002.

[10] A. T. Murray, "Route planning for harvest site access," Canadian Journal of Forest Research, vol. 28, no. 7, pp. 10841087, 1998.

[11] A. T. Murray, "Spatial restrictions in harvest scheduling," Forest Science, vol. 45, no. 1, pp. 45-52, 1999.

[12] P. Bettinger, D. Graetz, K. Boston, J. Sessions, and W. Chung, "Eight heuristic planning techniques applied to three increasingly difficult wildlife planning problems," Silva Fennica, vol. 36, no. 2, pp. 561-584, 2002.

[13] J. R. Vincent and C. S. Binkley, "Efficient multiple-use forestry may require land-use specialization," Land Economics, vol. 69, no. 4, pp. 370-376, 1993.

[14] IMAZON, Detalhamento do Macrozoneamento Ecológico Econômico do Estado do Pará: Áreas para Produção Florestal Manejada. Relatório Preliminar para Discussão, Governo do Pará. Secretaria Especial de Estado de Produção, Belém, Brazil, 2006.

[15] M. Lentini, D. Pereira, R. Celentano, and R. Pereira, Fatos Florestais da Amazônia 2005, IMAZON, Belém, Brazil, 2005.

[16] S. W. Stone, "Using a geographic information system for applied policy analysis: the case of logging in the Eastern Amazon," Ecological Economics, vol. 27, no. 1, pp. 43-61, 1998.

[17] A. Veríssimo, C. Souza Jr., S. Stone, and C. Uhl, "Zoning of timber extraction in the Brazilian Amazon," Conservation Biology, vol. 12, no. 1, pp. 128-136, 1998.

[18] IBGE, Diagnóstico ambiental da Amazônia Legal, IBGE, Rio de Janeiro, Brazil, 1997.

[19] A. Brandão Jr. and C. Souza Jr., Desmatamento nos Assentamentos de Reforma Agrária na Amazônia, IMAZON, Belém, Brazil, 2006.

[20] IBGE, Mapa do Potencial Agrícola e Topografia do Brasil. Atlas Nacional do Brasil, IBGE, Rio de Janeiro, Brazil, 4th edition, 2002.

[21] ISA, IMAZON, IPAM, ISPN, GTA, and CI, Seminário Consulta de Macapá 99: Avaliação e Identificação de Ações Prioritárias para a Conservação, Utilização Sustentável e Repartição dos
Benefícios da Biodiversidade na Amazônia, ISA, São Paulo, Brazil, 1999.

[22] P. Barreto, C. Souza Jr., R. Noguerón, A. Anderson, and R. Salomão, Human Pressure in the Brazilian Amazon Forests, World Resources Institute, IMAZON and Global Forest Watch, Belém, Brazil, 2006.

[23] C. Sabogal, M. Lentini, B. Pokorny et al., Manejo Florestal Empresarial na Amazônia Brasileira: Restrições e Oportunidades. Relatório Síntese, CIFOR, IMAZON, EMBRAPA, and IFT, Belém, Brazil, 2006.

[24] A. Veríssimo, E. Lima, and M. Lentini, Pólos Madeireiros do Estado do Pará, IMAZON, Belém, Brazil, 2002.

[25] J. Viswanathan and I. E. Grossmann, Discrete and Continuous Optimizer (DICOPT), Engineering Design Research Center (EDRC), Carnegie Mellon University, Pittsburgh, Pa, USA, 1999.

[26] D. K. Varvarezos, I. E. Grossmann, and L. T. Biegler, "An outerapproximation method for multiperiod design optimization," Industrial \& Engineering Chemistry Research, vol. 31, no. 6, pp. 1466-1477, 1992.

[27] M. Schulze, J. Grogan, and E. Vidal, “Technical challenges to sustainable forest management in concessions on public lands in the Brazilian Amazon," Journal of Sustainable Forestry, vol. 26, no. 1, pp. 61-76, 2007.

[28] R. Repetto and M. Gillis, Public Policies and the Misuse of Forest Resources, Cambridge University Press, Cambridge, UK, 1988.

[29] J. R. Vincent, "Rent capture and the feasibility of tropical forest management," Land Economics, vol. 66, no. 2, pp. 212-223, 1990. 

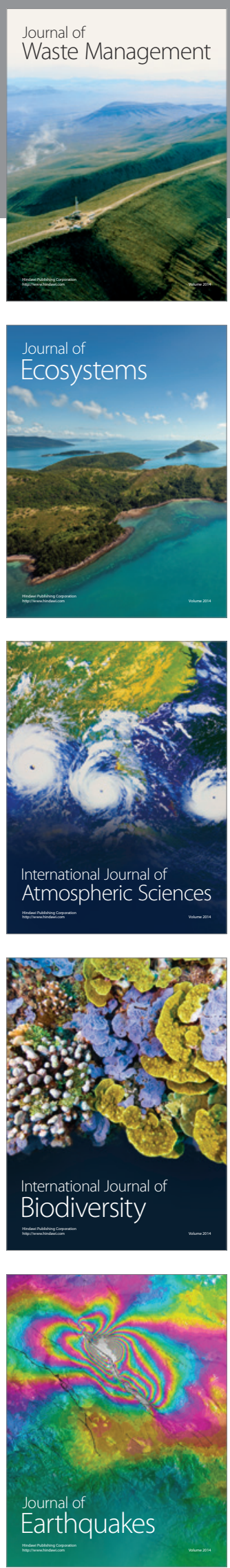
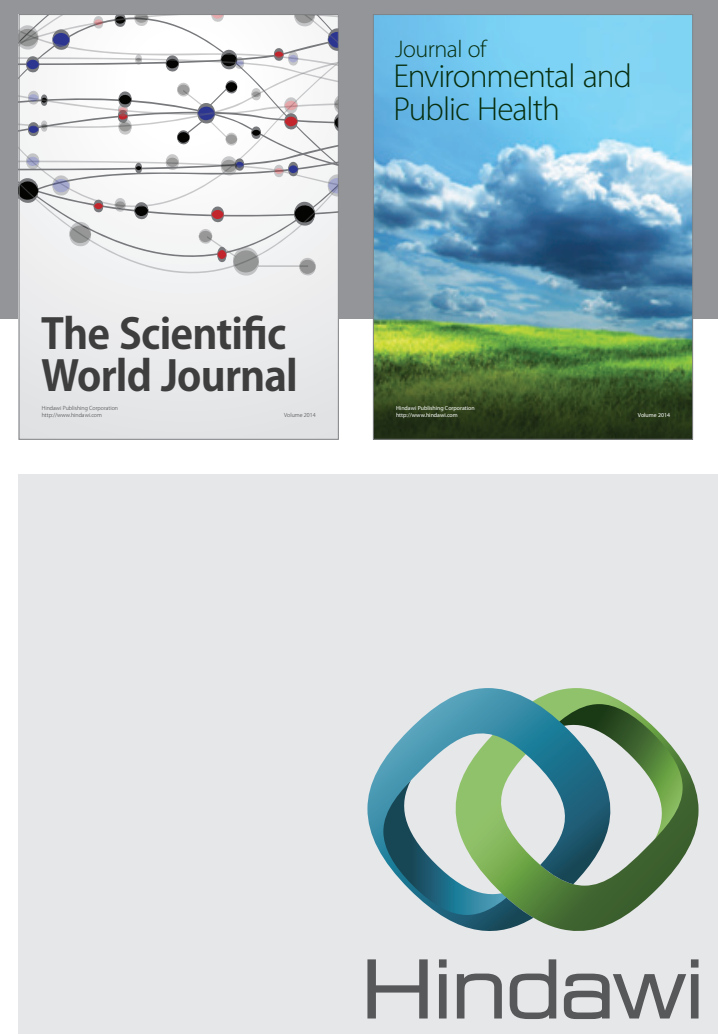

Submit your manuscripts at

http://www.hindawi.com
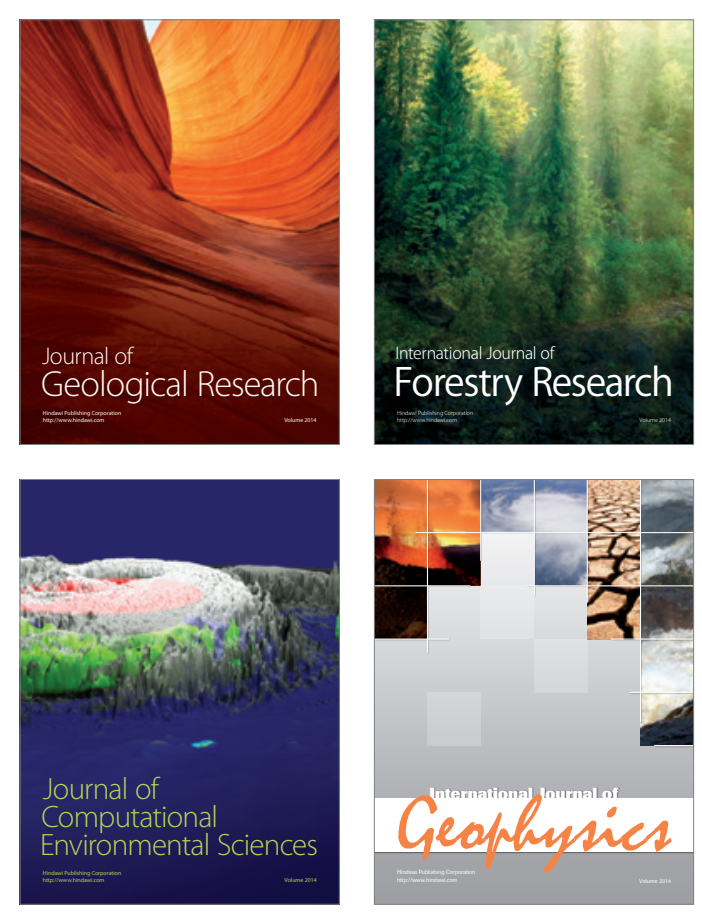
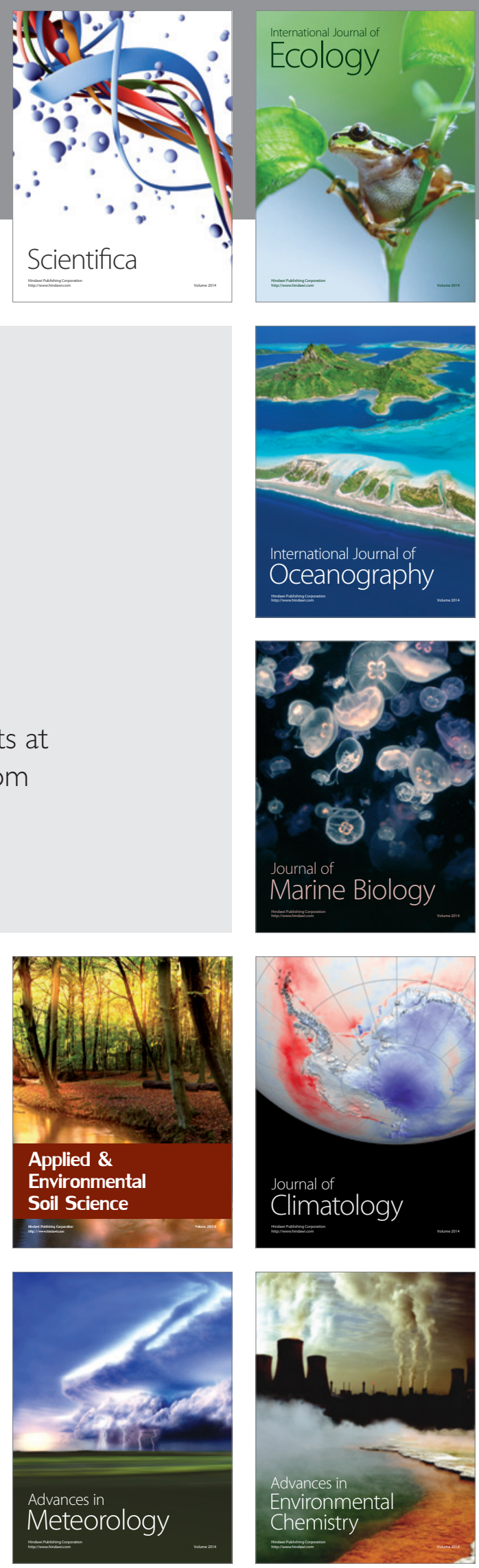